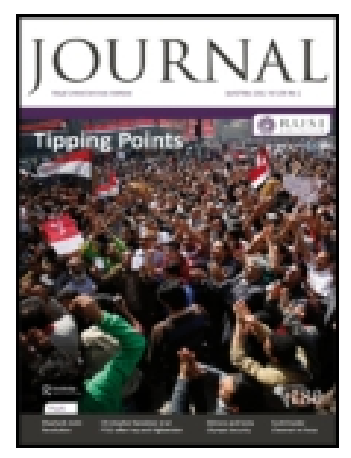

Royal United Services Institution. Journal

\title{
The Telephotos: A New Means of Electrical Signalling, by Night and Day, for the Naval, Military, Merchant Marine, Light-House, and Life- Saving Services. With Practical Demonstrations of its Application
}

\section{Colonel G. E. Gouraud}

To cite this article: Colonel G. E. Gouraud (1894) The Telephotos: A New Means of Electrical Signalling, by Night and Day, for the Naval, Military, Merchant Marine, Light-House, and Life-Saving Services. With Practical Demonstrations of its Application, Royal United Services Institution. Journal, 38:192, 103-114, DOI: 10.1080/03071849409416977

To link to this article: http://dx.doi.org/10.1080/03071849409416977

\section{Published online: 11 Sep 2009.}

Submit your article to this journal ¿

Џll Article views: 4

View related articles 주 


\section{The entmal}

\section{Bounal alnited Sertice alnstitution.}

Vol. XXXVIII. FEBRUari, 1894 .

No. 192.

[.1uthors alone arc responsible for the contents of their respective Papers.]

Friday, December 15, 1893.

The Rigur Hox. I.orv GEORGE HAMILTON, M.P., in the Chair.

IIHE TELEPHOTOS : $A$ NEIV MEANS OF ELECTRICA SIGNALLING, BY NIGH'T AND DAY, FOR 'IUL' NAVAL, MILTARY, MERCHANT MARINE, LIGH'THOUSE, ANI LIFE-SAVING SERVIUES. WITI PRACTICAL DFAKONSTRATIONS OF ITS APPLICATION.

$$
\text { By Colonel G. E. Gour.uo, (late) United States Arms. }
$$

Tho Cesikssy: I mast, in the first place, thank the Council for haring offercd me the honour of preeiding here to-day. My connection with the United Serrice Institution in the past has been purely of an administrative character, and thercfore I am rers thankful to those gentlemen who are upon tho Council that they hare enabled me, now that $I$ hare retired into prirate life, once more to renew my acquaintance rith an Institution which when I ras an oficial I took grcat interest in. TFe hare met to hear a lecture from a distinguished soldier, Colonel Gouraud, who is Fell known in the United States, not only $2 s$ an emineut ccicrtist, but nlso as an officer of great gallantry, and who has, amongst other recognitions of his enerit, receired the MIedal of Honour fer conspicuous serrice. IIe is good enouglt to undertake to explain a new system of electrical signalling, which $I$ am sure will be a matter of great intereat to both military and naral officers, but cspeciallyto tho latter. Wre must recollect that in these days the tendency is crers year to increase the molility of naral armaments and ships, and, conequentls, it is of the rery utmost impurtance, if that increased power of morement is to be utilized, that there should be the simplest and most effectire system of signalling amongst the ships thus moving, and one which is spccially arailable at night. I cannot cspress anj opinion upon the merits of this sjstem, because it is a matter which is bejond ine, but I feel sure that all here present will gire tho nost respectful. attention and heuring to the distinguished leeturer, and that thes will welcome. him with that cordiality with which the soldiers and sailors of our Service always. relcome an oflicer belonging to another Serrice, especially if he belongs to a raves which is the same as our owm, and speaks our own language. With these ferr prelininary obscrrations, I beg to introduce to sou Coloncl Gouraud.

Ix presuming to address an andience comprising so many distin. guished members of Her Majesty's Services as compose the Royal

rot. XxxyII. 
United Service Instituition of Great Britain, who have honoured ne by their presence here to-day, I feel that some apology is due; all the more so from tho fact that I understand there are present many eminent, indeed representative experts of the various signal serrices, to which the subject of my lecture moro directls appenls.

$A$ long ancl somewhat conspicuous identification with kindred subjects from a scientific point of view, together with the fact that uny participation in the military serrice of another conntrs during a memorable war of serèral ycars' duration, which gave tie many opportunitics for both witnessing, as well as experiencing to my very direct personal advintage, the incalculable value of in efficient signal service, may perhaps in some degrec excuse an otherwise unwarrantable presumption.

Having several times before had the honour of being invited to lecture in this Institution, but, unfortunately, always prevented by cither absence abroad or illiess, I have aviled myself of this the first opportunity afforded; and an fortunate in haring for my subject one not only in crery way peculiarly appropriate to this place nnd company, but involving as it does an absolntely now invention which is now exhibited and described for the first tine in any country. That it was -not first shown in the Uunited States is perhaps remarkable, - considering that it is tlie invention of an $A$ werican, a circumstance, I - am informed, which is duc to the fact of the keen interest taken in - the inrention by: a well kuown British maval oflicer of great experience, who chaneed to see the apparatus at the moment of its completion, and who so strongly aclvised its inventor to lose no time in bringing it to the notice of tho British authorities, that ho resolved to do so at once. It is alike to that samo British officer that I $\mathrm{am}$ myself inclebted for the pleasure and adiantige of liaviug made the acquaintance, only since his arrival in-Englaud, of a fellow-countrymain whom I hare found to possess, besides many high qualities of charactir, the gift of incentire genius of a remarkable order.

With these prefitory remirks, $\bar{I}$ have only to crave sour kind indulgence, which $I$ do with a confidence begotten of a long and linppy residence in a land we aro proud to think of as our nother country.

The Tclepliotos.

('Ihe invention of JIr. Claudius Victor Boughton, of Buffalo, N.Y.)

$\Lambda$ new means of electrical signalling by niglit and das, for naval, wilitary, merchnnt marine, lighthouse, and life-saving services. Its theory and construction, with demonstrations of its application. For the botter apprecintion of the advance in the science of signalling which is clained for this invention, it maj be convenient, moro especially for those of $\mathrm{my}$ hearers who are not experts in this special brancli of the Scrvices, if I touch bricfly upon the three most zapid and reliable systems now in use, namely, the flags and lieliograph for. 


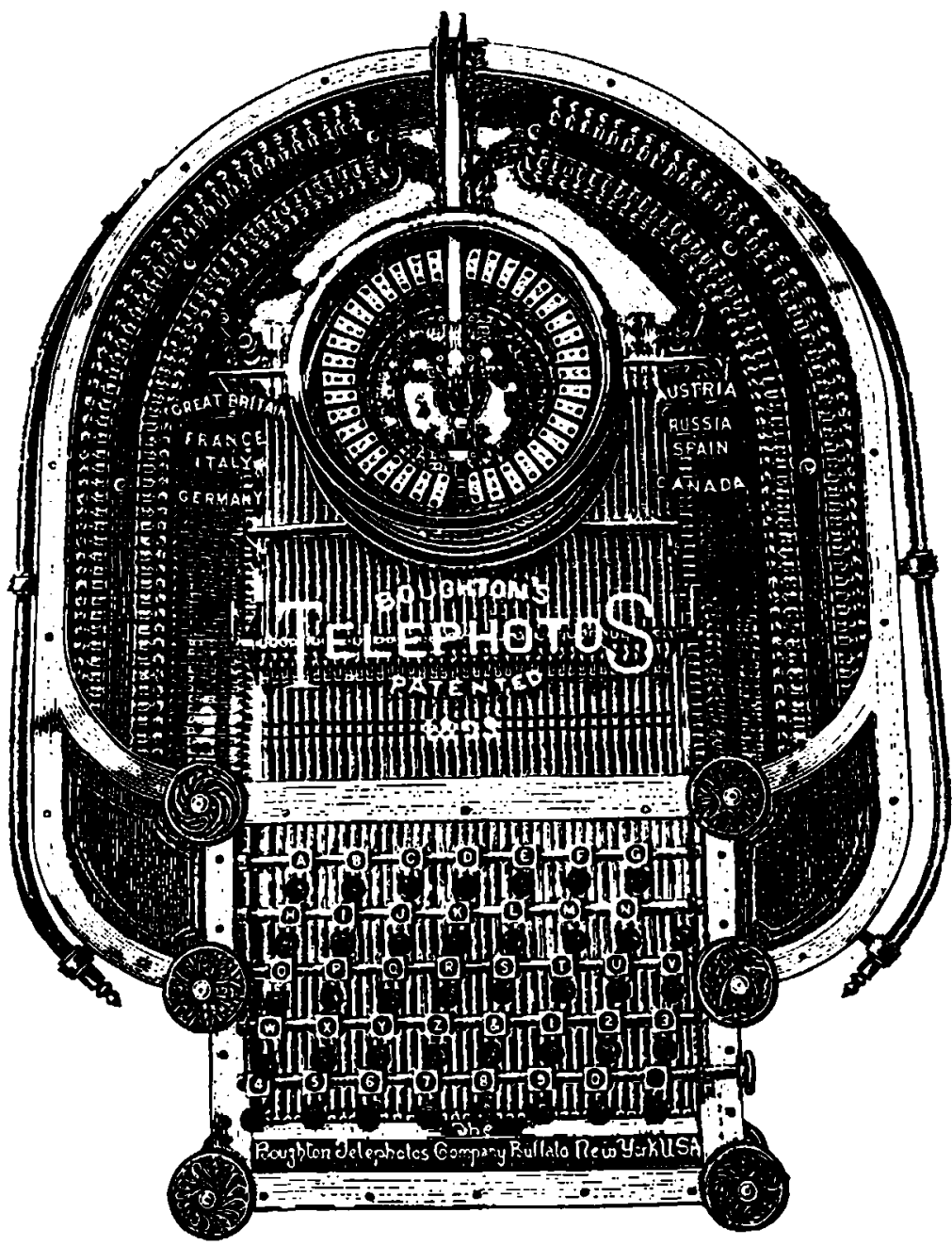

day, and the Colomb signals by night, conceding at once both their rapidity and accuracy; and then indicate the particulars in which they fall short of what is requircd, leaving sou to determine in the end whether I am right in the opinion I linve formed that $\mathrm{M}$ : Boughtou's invention fills an important gap.

Signalling by flags has not made any remarkable progress since the day of the historic signal "Engage the enemy more closely;" "England expects erery man will do his duty," which was displnyed with 33 flags in 13 hoists from Nelson's Hagship, the "Victors," at Trafalgar, while if the same signal had to be made to-day, it woild 
take 25 fings and 9 hoists. I ase the illustration merely to point the very small adrance which has been made in the flag s5stem sinec 1805 . Certain atmospheric conditions will dofeat all signalling by sight, some sjstems being more affectcd than others, but I presumo it is not too mach to eay that colours of flags are not distinguishable orer a milo in ordinary baze, and certainly not at that distanco in a moderately thick fog; and that in a calm the flags liare a tendency to hang up and down for minutes together, less so perhaps in these tlays of fast steaming than in the days of the wooden sailing ship, when hours instend of minutes often ruled, jet the probability remains that, with a large fleet at anchor, slips 2 miles from the flagship have difficulty in reading the Admiral's signals in a calm.

I learn that the niglit signals of Admiral Colomb have done, and are still doing, most efticient service in some ships which are not provided with electricity, and that ships having command of a cnrrent and provided with mast-head electric lights effect a saving of tine in displaying Admiral Colomb's time flash, with the obvious resalt that the increased brilliancy of the light carries with it the power of communicating to a greater distance; nerertheless, the system of the long and short fiash for night signalling is still the one in common use. I do not refer to the occasional use of the scarch light for the purpose. I quote from a pamphlet pnblished in 1866, and entitled "Commander Colomb's Patent Night Signals":-

"This system of night signals, fe.

"1. It requires less skill and less knowledge than the ordinary llarg signals in the daytime, and is not liable to crror.

"2. This system possesses also the greatest range, and is the enost japid system known for claylight and fog signals."

The first quotation is endorsed by the fact that the original Colomb lamp is still in use in many ships, and that the time flash by electric light is the ouly improrement which has been made upon it. The second quotation I am not in a position to offer any comment upon, and I only introduce it to emplinsize the adrance on Colonib's system clnimed for this new invention, which I shall presently reach.

I will now touch upon the heliograph, which, with the sun at command, is, of course, the most powerfal thy signaller known, far cxceeding in distance erery other.system; bat obrionsly useless when. the snn's nucertain rays are not at command.

Reflect for one moment on the Fort Ekowe cpisode of the Zulu War, with its picce of common looking-glass for day signalling and no arnilable means, beyond a common lamp, of communicating by nights, and consider the similar incidents other wars have furnished in the past and will doubtless furnish in the future.

I could point, of my own experience, to several instances of like feilure during the American War of the Rebellion.

The theory of the telephotos is the prodnction by electricity upon a shaft of incandescent lamps of any candle power, of tho sjmbols of the Morso alphabet and numerals, in dashes of $\check{\Xi} \mathrm{ft}$. length, made wit? 10 lighted lamps, and dots of 3 in., made with one lighted lamp, and with unlighted interrals of 5 ft. betirecn cach, which will bring und $42^{-}$ 
the eye the complete symbol at once, and is intended for use at any points within vision between which the laging of telegraph wires is impossible or impracticable.

Its Construction.-T'Te Telephotos is a combination of electrical conpections contained in a case mounted on a pedestal which is fastened to the floor, having a key-board of the niphabet and numerals, the same as that of a type-writing machine, and the keys have raised on their under side all the Mlorse characters in brass, with platinum points; the cross bars, 106 in number, are flexible and embedded in hard rubber. A groove under the keys contains a number of fine steel bicycle balls, with $\frac{1}{10}$ in. of lost notion, which is the thickness of a key, so that, when that space is occupied by jressing one kes down between the balls, all other kegs are locked. 'The kef, when pressed down, contacts with and conreys the current to the cross-bar by means of the raised s5mbol on the under-side of the key, from which cross-bar wires lead to the lamps on the light frame, which, when lighted, make the MLorse character corresponding to that on the key pressed down. The switch-board is 11 in. by 14 in., and has a capacity of controlling perfectly 106 incandescent lamps, and I think I am safe in saying that so many lamps have nerer before been controlled in so small a space. The lainp is one of nn entirely new design, representing in shape a round door-knob, witl a filament of 10 coils placed cross-wise, in order to secure the greatest light surface of the lamp; each lamp fits into a parabolic inetal reflector, and the front of each is covered with a paralleling lens, designed at the Cornell University for this invention.

IIero I must prenise that, to make the entire MIorse alphabet and numerals with separate lamps, 535 would be required, and would necessitate a shaft $270 \mathrm{ft}$. long; bat the inrentor, by an ingenious arrangement of his electrical connections, effects his object with 53 lamps in a shaft $27 \mathrm{ft}$. long by $3 \frac{1}{\mathrm{~s}}$ in. by 3 in., and in so using the 53 lamps to perform the work of 535 , you will obserro that, as the cur. rent is cut off from a s5mbol, the greater portion of the lamps which formed it aro instantly relighted to form the next s5mbol, and so, practically, the objection which might be suggested, that the expiring incandescence of the filament of tho lamp takes time to disappear, must be considerably modlifed in regard to the Telephotos; as i matter of fact, which you will presently see, the symbols are clearly defined and instantly cnt off, the expiring incandescence of the lamps not instantly relighted being rendered invisible by tho paralleling lens placed before each lamp. The ordinars telegraph key requires 129 motions to complete alphabet and numerals, as agrainst 38 motions on the Telcphotos.

Yon have before you, in the raised Morse symbol upon the kers, and the arrangement which insures that only one key at a time can switch the current which lights in tho lamp frame the necessars lamps for exhibiting complete the symbol of the key tonched, the essence of Mr. Bonghton's invention, and you will observe that not any lights in the frame, other than those forming the symbol displajed, can possibly be lighted. 
I ask your attention for a monent to the ingenions device contained within the cylinder which surmounts the key-board. It consists of the type arms used in the ordinnry type-mriting machine, and 36 doable magnets for throwing the Ronan typo of the symbol simultancously with its display on the light frame, on to a paper ribbon in order to preserre an unmistakable record of all communieations made by the Telephotos, which record, being under seal, the duly authorized nlone can hare access to, and a device is being fitted to an instrument now in course of nanufacture which will record the date and time of day any communication is made. The casual observer mas possibly consider that he is looking upon a maze of wires with complicated connections and consequent liability to derangement.

Although consisting of many parts, there are but very few that are movable, and their movernent is of such a nature that failure is im. possible, and wear and tear practically nil.

While the inventor bas certainly aimed to accomplish his object within the smallest possible space, and has almirably succeded, he has made no sacrifice of ccrtainty in the operntion of any part of his system. Indeed, us is the case with many marrels of science and inrention with which wo are familiar, so do I feel justified in deseribing the 'Telephotos in its entircty as simplicity itself.

\section{The Application of the Invention.}

The shaft is portable, and may be either oue-faced, or four-facel, as desired, to be hoisted to any point, or, laid horizontally in any conrenient position, or, along tho signal Jard; it can bo permanently. fitted on any line of available space on a ship's hull or starboard and port sides, nud across tho bow and stern parts, on a pole topmast swirelling aronnd it, or, the topmast conld be fitted with a four-faced shaft showing ahcad, astern, or abcam. A single or four-faced shaft, arranged to elevate to the perpendicular or lower as expedient, can ho fitted on a bridge, and can also be placed on the semaphore mast, lighthonses, and lightships, and, as theso latter aro brought into postal and telegraphic connection with the shore, the Telephotos will complete the circuit between const protecting navies as well as incoming and outgoing freight and passenger ships and the telegraphic centres on land: Liglitships which it may bo found difficult to connect with the land bj snbmarine cable. will hare-the rery best snbstitute in this invention.

$A$ light horse wagon is designed, for militaiy use and life-saving service with stranded ships, to carry a shaft of lights, dynamo, and engine the shaft lies horizontally on the vehicle, and can be raised and signalled from in $i \mathrm{few}$ seconds; the total weight, when complete, not exceeding $1,000 \mathrm{lbs}$.

Without in the least uecrying the importance of either the telegraph or telephone in field service, permit me to suggest that the Telephotos will accomplish what neither of these systerns can, to wit; frec cominunication along the coast between land and sea fores acting together. It can move side by side with an army in its strategic 
changes of position, and within vision limits by das or nightit be doing gool work long before wires can be laid to operate either telegraph or telcphone.

I know that signalling has obtained a high point of efliciency in the military Service, and I have every reason to believe the same of the naval Service; still maritime incidents have not been wanting of late which emplarise the pressing uecd in marine sigualling for the means of rapid interchange of orders, news, and opinions: one, an Atlantic liner, filled with passengers, lies disabled in mid-ocean, and passingr ships only bring to port news of the fact withont the faintest clue to its cause, and the public mind is racked with anxiety for days; another, a catastrophe, the memory of which will always aljide with us, and which, though scemingly led to by more than one contributory cause, nevertheless points clearly cnough to the fact that in marine signalling there is yreat room for means whereby free, rapid, and innambiguous expression can be giren to vital doubts.

'The application of the invention from the inventor's point of view has now to be demonstrated, and I would here observe that any practical illnstration of its ralne for actunl serrice would be an inpossibility in its present situation. Any discussion; therefore, which may follow the reading of this paper must of a necessity bo somewhat one-sided, for you are faniline with erery signalling system in use, and with the merits and demerits of each respectively, but this invention has set to be brought to practical test, and its result brought to light before any comparison can be instituted, aud its full value can lo apprecinted.

Farther back I said I would prescutly refer to the quotation. I made from the 1866 pamplet of Admiral Colomb, in order to emiphasize the apparcint advanco the Telephotos is upon tho iddmirnl's systcm, which is acknowledged to be the very best for night service erer used, observing that what the parnphlet affirms as true of the systein it sets forth must also be true of the 'l'clephotos, and the advance the latter is apon the system of Admiral Colomb is that it exhibits by one pressure of the finger a complete sjmbol, and simultaneously makcs a perfect record of it in Roman characters.

To dilate upon the superiority of the Telephotos as a night signaller orer Admiral Colomb's system is not the olject in view, but I hold the opinion, based upon a careful examination of the invention, that. when it is given a trial it will speak for itself with an eloquence more persuasiro than any within my command.

Tho lights at night will show as' far as any other lights of equal power, but the uso of the Comell lens gives an' increase of "one-third in the distance; and $\mathrm{Xr}$. Boughton informs me that at $2 \frac{1}{2}$ miles in bright sunshine and clear blue sky the 'Telephotos has been read with the aid of an ordiuary glass, while at night in ordinary conditions of atmosplere the same signals were distinctly read without a glass 6 miles. This experiment represents the greatest distance there las as set been an opportunity to try it; but, from the experiments made, Mrr. Boughton assures me thai he is confident that nnder similar conditions with the aid of field glasses such? as aitc 
ordinarily uscd, the signals can be distinctly and relinbly communi. cated a distance obriously suflicient for all practical naval requirements.

The only knomledge required is that of the Morse alphabet and numerals. Telegraph operators read the srmbols.in jights more rapidly than they do those of the oddinary telegraph, vecause the Jight symbol is presented to tho eye complete, and the letters of the alphabet and numerals upon the kegs sufficiently indicate their ase.

Given an expert telegraph operator to read the symbols, and an equally quick typewritirg clerk at the key-board, letters mado and read per minate by tho Telephotos must yreatly exceed the namber the telegraph could transmit in the same time. This will be readily understood by those familiar with telegraphy.

The wires connecting the "kers" and "lights" being practically unlimited as to leogth, the "lights" can bo assigned to ang point, and the "key-board" located at any distance from it ; tho intervening wircs between them, wrapped with water-proofing, form a cablo $\frac{g}{8}$ in. in diameter. A simple arrangement on the "key-board" by the turn of a thumbscrew, gires two changes for prirate signalling, and a third change for any cipber combiuation of which alphabet and uumerals are capable is provided for.

This key-board can be adapted to any light symbol. The Morso is used by the inrentor merely to exhibit the principlo of the T'elephotos, namely, that of showing a symbol in its cutirety. I make bold to suggest that, had the 'I'elephotos been on the bridge of the "Cnmperdown," it might have been the means of saring a million sterling, and of preserving the lives which went out with the "Victoria."

The invention as a whole, as presented for your considerntion, I fecl erery justification in pronouncing to be one of exceptional merit both in its conception and execution. As I have already stated, the apparatus before you is now shown in public for the first time; it, therefore, goes without saying that it lins not jet had tho advantage of baring been subjected to the cruvial test of practical service at sen, and while there is in the mind of the inventor no reason to doubt that it will realize all his expectations, he, with characteristic modesty, an!icipates that the criticisus and suggestions which will naturally emanito from the distinguished officers of Her Majesty's Service into whose hands it will naturally piss for trial may, pezhaps, lead to some modifications of more or less importance. Ho desires me to add that he will thankfully receive all such suggestions in the confident belicf that he can satisfnetorily meet them.

In conclusion, permit me to submit the question this paper suggests t) $\mathrm{me}-$

Is the Telephotos an iavention which, on trial, is likely to prove an important addition to the existing systens of signalling?

I have no doubt at least that the subject will receivo all due consideration at the hands of the anthorities of the rarious Services it concerns, and which must necessarilg include an exhaustive practical test of its many applications. 
To this end I understand MIr. Boughton is prepared to frecly place both himself and his invention at your disposal.

There only remains to me to express to you, my Lord, in the name of both MIr. Boughton and myself, our very sincere thanks for the great honour you hare done us in presiding at this meeting, and as rell to you, gentlemen, for both the honour of your presence and the very kind attention you hare nccorded to my remarks.

I have the further pleasure of introducing Mr. Boughton, who will ze both happy and able to supply my many deficiencies of description, together with tho important supplement of such prnctical demonstration as the somenhat limited dimensions of this hall will permit:

Mr. Bocgntox then gase a demonstration of the practical morking of the Telcphotos, explaining its details, and answering questions as to its adapiation to military and naral uses.

Admiral CaETELAND: I speak rith sone difidence on this subject, as I hare not deroted rery much attention to signalling; but it eecms to me that this instrument, for cxposing and occulting the light, is a sinilar application to that of ms fricad Admiral Celomb, when he introduced his flashing system sume jears ago. The only difference is, that this is an instrument for sigualling in form, whereas ddniral Colomb's was for signalling $b y$ mofion. All naral men will remember the hind of hurdy-gurdy box which Admiral Colomb introduced with his flashing sjgnals-tho application of the Morse ssstem. This box was rery soon discarded; it was found to bo perfectly unnecessary, and the exposure and oceultation of the lingth was effected entirely by hand. As far as I cun understand, we want a light that will Ehow all round, witli which wo can signal to any part of a fleet, and an clectric light fixed at the mast-hends, exposed and occulted by an electro-magnet, actuated by a kes in the connizg tower, is the direction in which we oungt to go, and, I believe, are at present looking. I am afraid that this instrument now before us, though beautifulls wade, is far too complicated for working on board ship. We mant something rery much more simple. I am very sorry to sny anything against it, but I do not thial that it is the thing we require for ship work.

Mr. QUAIX: I should like to ask whether it is the fact that the electrical lanip exhibited by Mr. Boughton is worked with the electro-magnet?

Mr. Bovantox: it is not. Thero is no incandescent lamp construeted with clectro-magnets, that I know of.

Mr. QUars: It was mentioned that these lamps had the qnality of electromagncts?

Mr. Botantox: This is not an clectro-magnet lamp at all; this is a simple incandescent light. 'There is a magnet connected witl this apparatus in recording. That is entirely cut off now from these lights, beenuse six of the kes3 in the instrument are defectire, oxing to the breakage of the glass. The magnets are not connected. If jou will look on the draning, you will see that it is a sinple incandescent light.

Admiral Sir Vesex HAyritos: I am afraid that this is such a wonderful change in signalling - it is so different from our preconecired notions - that we are all really rather amazed at present, and unprepared for discussion, and as I hear that these damps are to be put up on the Thames Fimbantment, I only regret that it has not been done before the lecture to-day, so that we might bare seen something of the results of actual practice before discussing it. Spealing for myself, I came here perfectly ignorsat on tho matter, hoping to hear what some of our able signalling officers unight hase to say about it. For instance, my friend Admiral Colomb, I think, might gire us some information which will be rery interesting.

Admiral CozoYs : Mf Lords and gentlemen, I do not think it is quite fair to dsaw me. Howerer, of courso I respond. The instrument exhibitcd for actuating the lights and the way in which the light is displajed aro perfect norelties to alf 
of us. We are introduced to a new set of idens, we may say, and I think we might quite casily, with our preconecired notions, not see at first the whole plan which is opened to the intentor's mind. First of all, I think his aim must be rapidity. It is perfectly well known that with the flashing $\$ 5 s t e m$, as it stands, we are cternalls working for greater rapidity. The? rapility he has got; about 20 words a minute, 100 letterg I think he said, happing to be the highest specd which my military collengue (Colonel Keyser), if I may call him so, who sits bchind me, has got with the fiashing system, and $I$ hope that le will be "drawn" as soon as I hare linished. 'Thes do in the armj 20 words a minute-I hare seen it myself-not: slurred orer, but done with absolute correctness, with corrections made, so that the message slrould come with perfect accuracy. 12 words a minute is their ordinary working speed. We hare not got as far as that in the nary jet, because the apparatus which can be uscd rith that speed for land serrice is not suitable for sea service, but it is perfectly certain, with the number of ofleces who are now engaged in the matter, that we sliall ultimately get that greater specd. Then, I think, in this way the aim of the inventor in getting greater specd will be, or I am afraid is likely to be to soyg extent, frustrated by the greater rapidity which is being fot gradually out of the flashing system. The system before us is one of signals by form ilmost alone. Fou must recullect that there are only three ways of making risible signals, either by difference of colour, by difference of form, or difference of motion ; commonly, two or more of those three things are combined, as in the llag ssstem. In this system there is a little colour used, just cuough to make the distinction. The llashing ssetcm is wholly motion; it has nothing whaterer to do with form or colour, but ererstling depends on comparisou of the times in which the symbols are proluced. The obeerver compares in his mind the difference of the time as they pass, and knows his signals accordingly. This is a new application of form by light siguals. It is nearest to the system of which, I think, Sir Alerander Jiluc was the author. He had a serics of lights placed rerticalis; they were, of course, not electric lights in those days, but they wero white lights at different distances apart, making a similar sort of arrangement to that rlich wo hare before us now, supposing that line of light was rertical. When you get electricity, you can do an infinite number of things which you could not do before it cristed, and the inrentor has shown the greatest possible shill in his contrirance, and must hare lad, I am sure, any number of elcepiess nights orer it. Ife mar bo mistaken, from his wint of practical kworledge of signalling, in the way in which he has applied it, but I can liardly help thinking thiat out of this maj come modifications which will be found excedingly useful. I am sure there is a great deal in these keys, and in the method of employing electricity, which is quite likely to be dercloped. There is a point we have to think of practically for the serrice of the llect. I am bound to say I do not in the least agrce with the oflicers who put it formard-but tho officers who do so are possibly much better judges than I an-there is a certain demand in the nury for "standing signals" for the manourring of the flect. I myself hare seen a flect manœurred for months with the Aashing ssstem; and, knowing that all our flects haro bcen manceurred for 25 or 30 jears entircly with the flashing system, cannot lay nucle stress upon this deinand; but many ofliecrs, Admiral Baird, for instince, a most prictical ofliccr, laj great stress unon the idea of hasing etanding signals for manciurring the flect at night, and for nothing else. IIe proposed to uso a line of vertical lights which might, by their colour and rarying distance apart, form a etanding signal which could be kept risible-not like the flashing system, a succession of vingals, but like a serics of lags-a standing signal which might be looked at as long as necessary by the flect, and migint be lept. showing as long as it was desired. Now, if you tale this system and put aside the iden of using the 3 rorsc, or the modified Jlorse, which the inventor has been usingif you take the instrunent itself and think of the possible modifications there mas be in the way of producing those standing signals which the nary has been working for, possibly souncthing might be done with it. I know nothing whaterer of $\mathbf{M r}$ r. Boughton; he was good enough to call upon une, and I am afraid I ras cxecsisicly rough witl him-not unduly rough I hope-because $I$ was not in a position to listeu to long cxplanations, and I had lo gatler the object of the insentor in a series of rery short, sliarp questions; but $I$ ambound to suy it struck me from his auswers 
that, berring the fact that he had no practical knowledge of sigualling, he hat the eort of mind which would be certain to come to right conclusions when he addled the practical kmowledgo of signalling to his knowlcdge of clectricity and to his: great michlianical skill. I nercr saw the instrument before to-dey, but I s:aw :s photographiof.it, and it, struck me that there was great skill displayed in it: construction: These are only thoughts that strike me at first. In all these rases $I$ know only onc way of going to work, unless the thing is absolutely ubsurd on the face of it, snd that is to try it against existing s5stems, to sec which way the wind blons, which.way the land lies. That is the only wny thith. I kriow of to get at the rights and wrongs of a question of this sort. I hope, my Iort, son will call upon my colleague behind ine to carry on the discussion.

Colonel Kerscr, C..B. (Inspector of Signalling, Aldershot) : I rise in obedience to the challenge of Almiral Colomb, though I do not think I liave anjthing to say, but as representing the army sigcallers I wish to explain to the inrentor that what we principally ain at is portability combined with simplicity, and at first ight this enormous mechnism rather takes ono's breath away. I. daresay when we come : to know it better wo shall seo other points about it, and if ro work together we ray be able to adapt it in somo was to our ryetem : but so far as I can sec at present I am afraid it is very much too cumbersone for any use in the fiell. I think for lixed stations, for forts, standing csmps, or answhere where we mag lxe for four or five months at a tine. it may be very useful indeed. Tho great adrantage would be that you would not hare to focus jour signal continually; erergbody could sco it without liaring to take the trouble of finding out the exact whereabouts of the piople with whon you are going to signal, hut beyond that $I$ am very much afruid it would be of very little use to the army.

Yr. Hovourox: In reply to Admiril Colomb and to Colonel Kegser, I wislt to ssy that I do not profess to bo an expert in signalling. I am cxlibiting a principle that crin be modificd in erery way. I lase had tho question asked me since I (ame here, how long I have sailed. Ary reply was, when I crosed the gang-planksof the "I'aris," to come to Europe, was the first time. I nerer up to that time raw a signal thrown.

Iord Gtoras Irixrmes (Chairnan) :. Well, ladies aud gentlemen, if nobody. has any further obscrvations to make or questions to put, I may discharge what i beliere is the duty of the Chairman, and a rery pleasant duty, on behaif of this mecting, to heartily thank Colonel Gouraud and $3[$ r. Hougliton for the lecture which they hare been good enough to delirer, and for the rery effectire mannein which we hase been shown by ceperiment and illustration the adrantages of the inrention which is brought before our notice. If the distinguished naval officer: who are present, and also if those in the room who hare a specinl knowledge of the training of eignalling men are unable to express any very definite opinion on this inrention, it is pretty clear that a poor iasman like myself is hopelessly in the dark. I carried nway with me from the nars certain ideas, and, those ideas being fer, I am rers tenacious of them. Tho one idea I got from iny connection with the Admiralt 5 was, the enormously increased power and the enormously increased mobility of ships of war: that means rapid concentration. Rapid concentration is not of nuch use unless that conceritration enables successul co-operation and combination, and euccessful co-operation and combination can al rags bo promoted and advanced by a simple and effective and rapid system of eiganlling. And thereforo I think that anybody who is good cnough to gire his attention to this particular subject and to make rarious suggestions, no natter in what dircetion. which will tend to increase and accelerate the cxisting system and methods, confers a very considerible service not only upon the navy, but also upon the army$I$ am sure it is in that senso that mo hare all listencd to this lecture. We hope that tho criticisms and the obscrvations that hare becn made will not be in anj way considered discouraging, but, on tho contrars, that thes may hare the effect of induciug both the gentlemen who hare been licre present to look at theso objections from a practical point of rier, and if thes do so Iet us eincerely hope that. they may be able so to orercome them as to make this instrument and this inrention ultimately a means of benefit to both Serrices. I think you will perliaps allow me to convey to Colonel Gouraud and IIr. Boughton our very hearty thanks for 
their goodness in being present here to-day and delircring the lecture to which we hare all listened with so much pleasure.

General Groras brseine : Ladies and gentlemen, we havo listened to a rery clcar and intercating lecture, and we hare scen experiments exhibited which haro no doubt giren a great deal of plensure to all present, and a roto of theaks has been accorded to the lecturer, which is quito riglet. Hut wo must not think that wo can allow our Chyirman to leare hia post without being tlanked for the rers great troublo which he must hare taken in coning here and presiding orer tho mecting on the present occasion. This Institution, I might be allowed to remark, owes a great deal to Lord Georgo IIamilton in the past, and rery probably in the future wo shall owe him a great deal more. Thereforo I think that our rote of chanks this crening should bo rery cordial indeed.

Admiral Sir Veser Hasintoy: I hsve very much pleasuro indecd in seconding the rote of thanks so ably propoed by the Chairman of this Institution, Qeveral Erskine, and $I$ hare the more pleasure in doing so from the fact that $I$ was associated with Lord Georgo IIamilton some part of the time whea he ruled orer tho Quecn's nars, a period which, I thint all naral men will agree with me, maj be described 13 the golden age of the nars.: Lord Acorge Hamilton is particularly fitted to preside orer this mecting. His lnowledge of all the details of the Idinirilty, not only the finaucial details but also of tho scientife details such as we hare before us, particularly qualifies him to preside orer this mecting.

'The scoolution was curried by acclonsation.

Lord Grosae IIAYILTOS: I am exceclingly obliged to jott. I was glad to be vnrcsent to-day. I take grcat intercst in this Institution. When I ras at the Idmiralty I fully rccognised its utility and did $\mathrm{mg}$ best to try snd secure for it a rather more fitting habitation than that which it now occupies. I beliero the results of those cndearours were successful. Fou are about to enter into a magnificent house, and I sincerels trust that when you get thero jou will be in the i)ossession of an income adequate and suitable to maintain it.

${ }^{1}$ In saying this I would observe I had nothing to do with the Niaral Defence Lct. But its principles and details were completely worled out beforo I went to the Adniralty. 


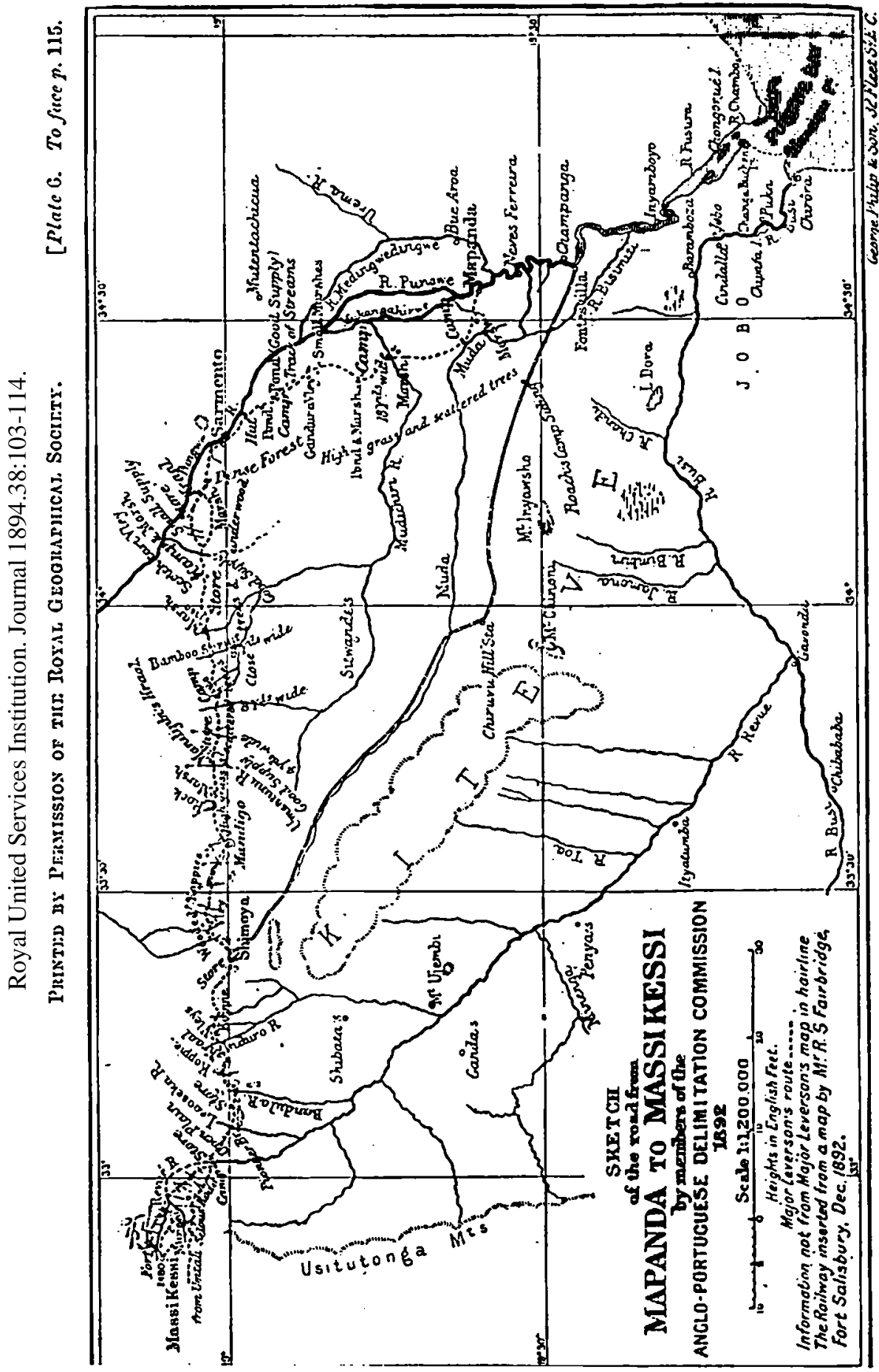

